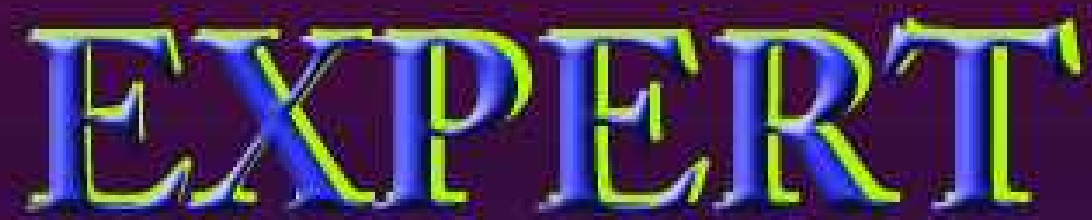

Jurnal Sistem Informasi

PENGEMBANGAN SISTEM APLIKASI LOKASI RUMAH KOST KABUPATEN PRINGSEWU BERBASIS WEB MOBILE

Elisabet Yunaeti Anggareni, Elieser Rudi HCN, Mad Muhaidi

KONSULTASI AKADEMIK BERBASIS ONLINE PROCESSING

Fenty Ariani, Robby Yuli Endra

PERENCANAAN ARSITEKTUR SISTEM INFORMASI MENGGUNAKAN MODEL ENTERPRISE ARCHITECTURE PLANNING (EAP)

di DIREKTORAT RESERSE KRIMINAL UMUM POLDA LAMPUNG

Hilda Dwi Yunita

DECISION SUPPORT SYSTEMMENGGUNAKAN METODE SAW DALAM MENENTUKAN KINERJA APARATUR PEMERINTAH KECAMATAN

M. Islam Mahdi, Rinawati, Tri Susilowati, Zul Kirom

PEMILIHAN CAFE TERBAIK MENGGUNAKAN METODE ANALYTICAL HIERARCHY PROCESS ( AHP)

Sti Ipnuwati, Khusnul Khotimah, Keni Puspita Sari

PEMETAAN COBIT 4.1 UNTUK PENILAIAN KEMATANGAN TATA KELOLA TI Yuthsi Aprilinda, Ayu Kartika Puspa

ISSN : 2088-5555 


\section{Expert}

Jurnal Manajemen Sistem Informasi dan Teknologi

Volume 08, Nomor 01, Juni 2018

\begin{tabular}{|l|l|}
\hline Judul & Hal \\
\hline $\begin{array}{l}\text { PENGEMBANGAN SISTEM APLIKASI LOKASI RUMAH } \\
\text { KOST KABUPATEN PRINGSEWU BERBASIS WEB MOBILE }\end{array}$ & $1-4$ \\
\hline $\begin{array}{l}\text { KONSULTASI AKADEMIK BERBASIS ONLINE } \\
\text { PROCESSING }\end{array}$ & $5-13$ \\
\hline $\begin{array}{l}\text { PERENCANAAN ARSITEKTUR SISTEM INFORMASI } \\
\text { MENGGUNAKAN MODEL ENTERPRISE ARCHITECTURE } \\
\text { PLANNING (EAP) di DIREKTORAT RESERSE KRIMINAL }\end{array}$ & $13-21$ \\
UMUM POLDA LAMPUNG & \\
\hline $\begin{array}{l}\text { DECISION SUPPORT SYSTEMMENGGUNAKAN METODE } \\
\text { SAW DALAM MENENTUKAN KINERJA APARATUR }\end{array}$ & $22-28$ \\
PEMERINTAH KECAMATAN & $29-38$ \\
\hline $\begin{array}{l}\text { PEMILIHAN CAFE TERBAIK MENGGUNAKAN METODE } \\
\text { ANALYTICAL HIERARCHY PROCESS AHP) }\end{array}$ & $39-48$ \\
\hline $\begin{array}{l}\text { PEMETAAN COBIT 4.1 UNTUK PENILAIAN } \\
\text { KEMATANGAN TATA KELOLA TI }\end{array}$ & \\
\hline
\end{tabular}

Fakultas Ilmu Komputer

Universitas Bandar Lampung

\begin{tabular}{|l|l|l|l|l|}
\hline JMSIT & Volume 08 & Nomor 01 & Lampung, Juni 2018 & ISSN 2088-5555 \\
\hline
\end{tabular}




\section{TIM PENYUNTING}

\section{Penanggung Jawab}

Ahmad Cucus, S.Kom., M.Kom.

Ketua Tim Redaksi:

Taqwan Thamrin, ST, M.Sc.

Penyunting Ahli (Mitra Bestari):

Mustofa Usman, Ph.D (Universitas Lampung)

Dra. Wamiliana, MA., Ph.D (Universitas Lampung)

Iing Lukman, M.Sc., Ph. D (Universitas Malahayati)

\section{Penyunting:}

Handri Santoso, M.Eng., Dr. Eng

Fenty Ariani, S.Kom, M.Kom

Robby Yuli Endra, S.Kom.,M.Kom

Ayu Kartika Puspa, S.Kom, M.TI

Erlangga, S.Kom, M.Kom

Pelaksana Teknis:

Wingky Kusuma, S.Kom

\section{Alamat Penerbit/Redaksi:}

Pusat Studi Teknologi Informasi

Fakultas Ilmu Komputer

Universitas Bandar Lampung

Gedung M Lt.2

Jl. ZA Pagar Alam No.89, Gedong Meneng, Rajabasa

Bandar Lampung

Email: jurnalfik@ubl.ac.id 


\title{
KONSULTASI AKADEMIK BERBASIS ONLINE PROCESSING
}

\author{
Fenty Ariani ${ }^{\# 1}$, Robby Yuli Endra ${ }^{* 2}$ \\ ${ }^{1}$ Program Studi Sistem Informasi, ${ }^{2}$ Program Studi Informatika \\ FakultasIlmu KomputerUniversitas BandarLampung \\ Jl. Z.A. Pagar Alam No 26 Labuhan Ratu Bandar Lampung \\ ${ }^{1}$ fenty.arianieubl.ac.id \\ ${ }^{2}$ Robby $\cdot$ yuliendra@ubl.ac.id
}

\begin{abstract}
Abstrak
Sistem Informasi bertujuan untuk mempermudah administrasi akademik khususnya pada kegiatan konsultasi proposal dan skripsi sampai dengan administrasi wisuda, yang awalnya semua kegiatan tersebut di lakukan secara manual, sekaligus untuk mengurangi penggunaan kertas (paperless) dan mendukung perkembangan yang sedang berjalan di Universitas Bandar Lampung yaitu UBL menuju digital kampus. Pembuatan Sistem Informasi ini menggunakan pemrograman Web.Adobe Dreamweaver 2014 yang digunakan sebagai tools untuk membangun aplikasi. Metode yang digunakan yaitu Online Processing dimana Sistem Informasi ini hanya dapat dijalankan dalam keadaan Online atau terhubung dengan internet. Sistem Informasi ini dibuat berdasarkan hasil kuesioner dan pengambilan sampel acak berdasar area (Cluster Random Sampling) yang telah disebar ke beberapa responden (mahasiswa yang tengah menjalani proses konsultasi proposal dan skripsi). Dari hasil kuesioner tersebut maka dibuatlah aplikasi ini.
\end{abstract}

\section{Kata kunci :, Online Processing, Konsultasi Online}

\section{PENDAHULUAN \\ 1.1 Latar Belakang}

Universitas Bandar Lampung merupakan salah satu universitas swasta yang cukup terkenal di provinsi Lampung. Mahasiswa yang telah memenuhi syarat pasti akan masuk ke tahap penulisan proposal yang selanjutnya dijadikan sebagai skripsi (tugas akhir) ataupun syarat untuk lulus (wisuda). Adapun mahasiswa yang mulai memasuki proses penulisan tersebut pasti membutuhkan pembimbing akademik ataupun pembimbing skripsi untuk membimbing mahasiswa tersebut selama proses penulisan. Proses tersebut tentunya sangat berpengaruh bagi mahasiswa yang telah memasuki tahap itu, karna banyak diantaranya yang membutuhkan kemudahan dalam proses tersebut

Kebutuhan Sistem Informasi dimasa sekarang termasuk kedalam kebutuhan yang penting, dikarenakan sebuah sistem merupakan penunjang dalam sebuah kegiatan. Sistem dan Teknologi Informasi memberikan pengaruh yang sangat besar pada kehidupan manusia, contohnya pada bidang pelayanan akademik mahasiswa, dengan diterapkannya teknologi informasi terbukti meningkatkan efektifitas dan efisiensi kinerja. Semakin banyak sistem yang dibuat untuk mempermudah dan meningkatkan efisiensi kerja di bidang akademik mahasiswa, Saat ini Universitas Bandar Lampung menuju Digital Campus, mulai dibangun sistem informasi berbasis komputer pada semua aktifitas akademik yang ada saat ini, tetapi dalam proses konsultasi dan administrasi skripsi masih belum terotomatisasi dan belum menggunakan sistem, sulitnya mendapatkan waktu yang sama antara dosen dan mahasiswa untuk melakukan konsultasi membuat terhambatnya kegiatan konsultasi, banyaknya kertas yang terbuang akibat revisi dan untuk administrasi sidang, belum mendukung adanya Digital Campus yang mulai diterapkan dan menjadikan kurang efisiennya pelayanan akademik di Universitas Bandar Lampung. (Ariani, 2017)

Dari kelemahan sistem yang belum terotomatisasi, untuk mengurangi penggunaan kertas, dan untuk mendukung perkembangan yang berjalan pada kampus saat ini, dimungkinkan untuk dirancang solusi dengan sebuah sistem informasi berbasis komputer pada proses konsultasi dan administrasi guna mengatasi masalah yang ada. Salah satu metode yang memungkinkan untuk digunakan dalam perancangan sistem ini yaitu Online Processing. Online Processing adalah sebuah sistem yang mengaktifkan semua periferal sebagai pemasok data dalam kendali komputer induk, informasi-informasi yang muncul merupakan refleksi dari kondisi data yang paling mutakhir, karna setiap perkembangan data baru akan terus diupdatekan ke data induk. Pada Online Processing, waktu yang dibutuhkan untuk mengupdate database relatif lebih cepat. Dari latar belakang diatas, penulis berkesimpulan untuk mengambil judul "Konsultasi Berbasis Online Processing Untuk Pengajuan Proposal dan Skripsi di Universitas Bandar Lampung". 


\subsection{Identifikasi Masalah}

Berdasarkan latar belakang diatas, identifikasi masalah yang muncul dalam penelitian ini adalah

1. Keterbatasan waktu pada proses konsultasi

2. Banyaknya penggunaan kertas atau kertas yang terbuang.

3. Proses administrasi konsultasi belum mendukung adanya Digital Campus yang mulai diterapkan di Universitas Bandar Lampung

4. kurangnya kontribusi mahasiswa kepada dosen pembimbing saat akan konsultasi.

5. Masih banyak mahasiswa yang belum paham dan mengerti dengan sistem pendaftaran yudisium dan wisuda yang ada saat ini

\subsection{TujuanPenelitian}

Adapun tujuan yang ingin dicapai dalam penelitian ini :

1. Untuk mengurangi penggunaan kertas, serta meningkatkan kepuasan mahasiswa terhadap kinerja layanan yang diberikan.

2. Membangun sistem informasi untuk kegiatan konsultasi dan administrasi skripsi pada Universitas Bandar Lampung.

3. Memberikan kemudahan untuk instansi kampus khususnya staff di fakultas dalam pendaftaran dan administrasi proposal hingga skripsi.

\subsection{Manfaat Penelitian.}

ini yaitu :

Adapun manfaat yang didapat dari penelitian

1. Keterbatasan waktu pada proses bimbingan menjadi teratasi.

2. Berkurangnya penggunaan kertas, proses administrasi konsultasi mendukung adanya digital campus yang diterapkan Universitas.

3. Mempersingkat dan mempermudah instansi kampus untuk pendataan calon peserta sidang dan calon wisudawan/i.

\section{TINJAUAN PUSTAKA DAN LANDASAN TEORI}

\subsection{Penelitian Terdahulu}

Development Of Online Project Registration and Management System (Eprm) for Masters By Coursework, penelitian ini membahas tentang pengembangan proyek kursus pendaftaran dan sistem manajemen untuk mahasiswa pascasarjana diDepartemen Teknik Elektro, Elektronik dan Sistem (JKEES). Dengan sistem ini, proses penting seperti pemilihan supervisor, judul proyek, tugas dan penyampaian laporan dapat dilakukan secara online. Penilaian oleh beberapa pihak juga dapat dilakukan secara online. Selanjutnya pemantauan proyek terutama dilakukan oleh koordinator program bisa dilakukan dengan mudah. Sistem online bernama ePRM ini dapat diakses oleh mahasiswa pascasarjana, pengawas, pemeriksa dan koordinator program.

Online Processing Of Novel Noun-Noun Compounds : Eye Movement Evidence, Jurnal ini memaparkan tentang eksperimen menyelidiki pemrosesan kata benda anyun-kata benda secara online. Percobaan membandingkan pengolahan kata yang sulit untuk ditafsirkan secara terpisah dan urutan kata sifat dan kata benda yang lebih mudah ditafsirkan. Dalam ketiga percobaan tersebut, waktu membaca pertama kali lebih lama terjadi pada kalimat yang sulit. Pada pengucapan kalimat pertama dengan pembacaan ulang kalimat yang sama untuk kedua kalinya sangat berpengaruh terhadap total waktu.

Web Service Personalized Quality of Service Prediction via Reputation-Based Matrix Factorization Jurnal inimemprediksi nilai QoS layanan Web yang tidak diketahui. RMF pertama menghitung reputasi masing-masing pengguna berdasarkan nilai QoS yang dikontribusikan untuk mengukur kredibilitas pengguna, dan kemudian mempertimbangkan reputasi pengguna mencapai prediksi QoS yang lebih akurat.

Dari penelitian yang pernah dilakukan, membuat penulis mengambil langkah untuk menggunakan metode online processing pada sistem informasi konsultasi dan administrasi yang akan dibuat

\subsection{Konsultasi}

Pertukaran pikiran untuk mendapatkan kesimpulan (nasihat, saran, dan sebagainya) yang sebaik-baiknya. Konsultasi menurut wiktionary adalah sebuah pertemuan atau konferensi untuk saling bertukar informasi dan saran. Konsultasi didefinisikan sebagai sebuah proses dialog yang mengarah kepada sebuah keputusan. (Al-Athway, 2004)

\subsection{Proposal}

Pengertian proposal menurut KBBI adalah rencana yang dituangkan dalam bentuk rancangan kerja, perencanaan secara sistematis, matang dan teliti yang dibuah oleh peneliti sebelum melaksanakan penelitian, baik penelitian di lapangan (field research) maupun penelitian di perpustakaan (library research). (Hasnun, 2007)proposal adalah rencana yang disusun utnuk kegiatan tertentu. (Heizer, 2006) proposal adalah alat bantu manajemen standar agar menajemen dapat berfungsi secara efisien.

\subsection{Sistem Informasi Berbasis Komputer}

Sistem informasi berbasis komputer merupakan suatu sistem pengolahan data menjadi informasi yang berkualitas dan digunakan senbagai alat bantu dalam pengambilan keputusan, 
koordinasi dan kendali serta visualisasi dan analisis. Dengan kata lain, sistem informasi berbasis komputer mengandung arti bahwa komputer memiliki peran yang sangat penting dalam sistem pembangkit informasi. Melalui integrasi yang dimiliki antar subsistem, sistem informasi akan mampu menyediakan informasi yang cepat, tepat, akurat, dan berkualitas sesuai dengan manajemen yang membutuhkan.

\subsection{Online Processing}

Adalah sebuah sistem yang mengaktifkan semua periferal sebagai pemasok data, dalam kendali komputer induk. Informasi-informasi yang muncul merupakan refleksi dari kondisi data yang paling mutakhir, karena setiap perkembangan data baru akan terus diupdatekan ke data induk. Salah satu contoh penggunaan online processing adalah transaksi online. Dalam sistem pengolahan online, transaksi secara individual dientri melalui peralatan terminal, divalidasi dan digunakan untuk mengupdate dengan segera file komputer. Hasil pengolahan ini kemudian tersedia segera untuk permintaan keterangan atau laporan.

\subsection{Sistem}

Sistem adalah sekelompok unsur yang erat hubungannya satu dengan yang lain, yang berfungsi bersama-sama untuk mencapai tujuan.

Sistem adalah kumpulan dari elemen-elemen yang berinteraksi untuk mencapai suatu tujuan tertentu. sistem ini menggambarkan suatu kejadiankejadian dan kesatuan yang nyata adalah suatu objek nyata, seperti tempat, benda, dan orang-orang yang betul-betul ada dan terjadi (Jogiyanto, 2005).

\subsection{Xampp}

Xampp adalah perangkat lunak bebas, yang mendukung banyak sistem operasi, merupakan kompilasi dari beberapa program. Fungsinya adalah sebagai server yang berdiri sendiri (localhost), yang terdiri atas program Apache HTTP Server, MySQLdatabase dan penerjemah bahasa yang ditulis dengan pemrograman PHP dan Perl. Nama XAMPP merupakan singkatan dari X (empat sistem operasi apapun), Apache, MySQL, PHP dan Perl. Program ini tersedia dalam GNU General Public License dan bebas, merupakan web server yang mudah digunakan yang dapat melayani tampilan halaman webyang dinamis. Web Service

Web service adalah aplikasi sekumpulan data (database), perangkat lunak (software) atau bagian dari perangkat lunak yang dapat diakses secara remote oleh berbagai piranti dengan sebuah perantara tertentu. Secara umum, web service dapat diidentifikasikan dengan menggunakan URL seperti hanya web pada umumnya. Namun yang membedakan web service dengan web pada umumnya adalah interaksi yang diberikan oleh web service. Berbeda dengan URL web pada umumnya, URL web service hanya menggandung kumpulan informasi, perintah, konfigurasi atau sintaks yang berguna membangun sebuah fungsi-fungsi tertentu dari aplikasi.

Web service dapat diartikan juga sebuah metode pertukaran data, tanpa memperhatikan dimana sebuah database ditanamkan, dibuat dalam bahasa apa, sebuah aplikasi yang mengkonsumsi data, dan di platform apa sebuah data itu dikonsumsi. Menurut W3C Web services Architecture Working Group pengertian Web service adalah sebuah sistem software yang di desain untuk mendukung interoperabilitas interaksi mesin ke mesin melalui sebuah jaringan. Interfaceweb service dideskripsikan dengan menggunakan format yang mampu diproses oleh mesin (khususnya WSDL).

Web pada umumnya digunakan untuk melakukan respon dan request yang dilakukan antara client dan server. Sebagai contoh, seorang pengguna layanan web tertentu mengetikan alamat url web untuk membentuk sebuah request. Request akan sampai pada server, diolah dan kemudian disajikan dalam bentuk sebuah respon. Dengan singkat kata terjadilah hubungan client-server secara sederhana. Sedangkan pada web service hubungan antara client dan server tidak terjadi secara langsung. Hubungan antara client dan server dijembatani oleh file web service dalam format tertentu. Sehingga akses terhadap database akan ditanggani tidak secara langsung oleh server, melainkan melalui perantara yang disebut sebagai web service. Peran dari web service ini akan mempermudah distribusi sekaligus integrasi database yang tersebar di beberapa server sekaligus.

\subsection{MySQL}

MySQL adalah sebuah perangkat lunak system manajemen basis data SQL (DBMS) yang multithread, dan multi-user. MySQL adalah implementasi dari system manajemen basisdata relasional (RDBMS). MySQL dibuah oleh TcX dan telah dipercaya mengelola sistem dengan 40 buah database berisi 10.000 tabel dan 500 di antaranya memiliki 7 juta baris.

\section{METODE PENELITIAN}

\subsection{Analisa Kebutuhan}

\subsubsection{Kebutuhan Software (Perangkat Lunak)}


Dibawah ini merupakan kebutuhan perangkat lunak yang digunakan untuk mengimlementasikan aplikasi yang akan dibangun :

a. Windows 7 digunakan sebagai Sistem Operasi

b. Adobe Dreamweaver 2014 digunakan sebagai tools untuk membangun aplikasi

c. Xampp Control Panel Application Versi 5.3.8 berfungsi sebagai server yang berdiri sendiri

d. PHP digunakan untuk menyambungkan antara HTML dan MySQL

e. MySQL digunakan sebagai perangkat lunak pembuat database.

\subsubsection{Kebutuhan Hardware (Perangkat Keras)}

Hardware yang digunakan untuk membangun aplikasi ini adalah menggunakan laptop Asus dengan Sistem Operasi Windows 7. Spesifikasi laptop yang digunakan adalah sebagai berikut :

Laptop Asus, Processor : Intel®Celeron® CPU 1007U @ 1.50GHz, Instaled Memory (RAM): 2.00GB (1,89 GB usable), Syatem Type: 64-bit Operating system

\subsubsection{Metode Pengumpulan Data}

Metode pengumpulan data pada penelitian ini terdiri dari beberapa teknik yaitu sebagai berikut :

a. Wawancara

Teknikpengumpulann data yang dilakukan melalui tatap muka dan tanya jawab langsung antara peneliti dan narasumber. Seiring perkembangan teknologi, metode wawancara dapat pula dilakukan melalui media-media tertentu, misalnya telepon, email, atau skype.

\section{b. Observasi (Pengamatan langsung)}

Metode pengumpulan data yang kompleks karena melibatkan berbagai faktor dalam pelaksanaannya. Metode pengumpulan data observasi tidak hanya mengukur sikap dari responden, namun juga dapat digunakan untuk merekam berbagai fenomena yang terjadi. Teknik pengumpulan data observasi cocok digunakan untuk penelitian yang bertujuan untuk mempelajari perilaku manusia, proses kerja, dan gejala-gejala alam. Metode ini juga tepat dilakukan pada responden yang kuantitasnya tidak terlalu besar.

\section{c. Studi Pustaka}

Segala usaha yang dilakukan oleh peneliti untuk menghimpun informasi yang relevan dengan topik atau masalah yang akan atau sedang diteliti. Informasi itu dapat diperoleh dari buku-buku ilmiah, laporan penelitian, karangan-karangan ilmiah, tesis dan disertasi, peraturan-peraturan, ketetapan-ketetapan, buku tahunan, ensiklopedia, dan sumber-sumber tertulis baik tercetak maupun elektronik lain. d. Kuesioner

Suatu teknik pengumpulan informasi yang memungkinkan analis mempelajari sikap-sikap, keyakinan, perilaku, dan karakteristik beberapa orang utama di dalam organisasi yang bisa terpengaruh oleh sistem yang diajukan atau oleh sistem yang sudah ada. Dengan menggunakan kuesioner, analis berupaya mengukur apa yang ditemukan dalam wawancara, selain itu juga untuk menentukan seberapa luas atau terbatasnya sentimen yang diekspresikan dalam suatu wawancara.

Pada penelitian ini, peneliti menggunakan kuesioner yang bertujuan untuk memperoleh nilai akurat terhadap kegiatan konsultasi akademik di Universitas Bandar Lampung. Pada penelitian ini akan dilakukan penyebaran kuesioner dengan sampel 48 responden kepada mahasiswa Fakultas Ilmu Komputer Universitas Bandar Lampung secara berkelompok. Berikut Pertanyaan dalam kuesioner yang telah disebar :

Keterangan jawaban :
a : Sangat tidak benar
d. Benar
$\mathrm{b}$ : Tidak benar
e. Sangat benar
c : Kurang benar

Tabel 1 Kuesioner

\begin{tabular}{|l|l|l|l|l|l|l|}
\hline No & \multicolumn{1}{|c|}{ Pertanyaan } & \multicolumn{5}{|c|}{ Jawaban } \\
\hline 1 & $\begin{array}{l}\text { Dosen selalu } \\
\text { mempunyai waktu } \\
\text { luang untuk kegiatan } \\
\text { konsultasi proposal }\end{array}$ & a & b & c & d & e \\
\hline 2 & $\begin{array}{l}\text { Kegiatan konsultasi } \\
\text { proposal dapat di } \\
\text { lakukan dimana saja } \\
\text { dan kapan saja }\end{array}$ & b & c & d & e \\
\hline 3 & $\begin{array}{l}\text { Kegiatan konsultasi } \\
\text { proposal saat ini } \\
\text { sudah efektif dan } \\
\text { efesien }\end{array}$ & b & c & d & e \\
\hline 4 & $\begin{array}{l}\text { Dosen memberikan } \\
\text { jadwal a } \\
\text { mahasiswa untuk } \\
\text { konsultasi }\end{array}$ & b & c & d & e \\
\hline 5 & $\begin{array}{l}\text { Mahasiswa } \\
\text { menunggu lama saat } \\
\text { ingin konsultasi }\end{array}$ & a & b & c & d & e \\
\hline
\end{tabular}

Dari kuesioner yang telah diisi oleh 48 responden, peneliti menghitung hasil kuisioner tersebut menggunanakan metode Skala Likert, Skala Likert adalah skala yang digunakan untuk mengukur persepsi, sikap atau pendapat seseorang 
atau kelompok mengenai sebuah peristiwa atau fenomena sosial, berdasarkan definisi operasional yang telah ditetapkan oleh peneliti. Skala ini merupakan suatu skala psikometrik yang biasa diaplikasikan dalam angket dan paling sering digunakan untuk riset yang berupa survei, termasuk dalam penelitian survei deskriptif. Dengan Skala Likert, variabel yang akan diukur dijabarkan menjadi indikator variabel dalam pengukuran bidang pendidikan.

Tabel 2 Hasil Kuesioner

\begin{tabular}{|c|c|c|c|c|c|}
\hline \multirow{2}{*}{$\begin{array}{c}\text { Keterangan } \\
\text { Jawaban }\end{array}$} & \multicolumn{5}{|c|}{ Pertanyaan } \\
\cline { 2 - 6 } & $\mathbf{1}$ & $\mathbf{2}$ & $\mathbf{3}$ & $\mathbf{4}$ & $\mathbf{5}$ \\
\hline A & 31 & 18 & 16 & 11 & 19 \\
\hline B & 9 & 15 & 24 & 9 & 18 \\
\hline C & 5 & 7 & 4 & 15 & 7 \\
\hline D & 3 & 6 & 3 & 10 & 3 \\
\hline E & 0 & 2 & 1 & 3 & 1 \\
\hline
\end{tabular}

Tabel 3 Bobot Nilai

\begin{tabular}{|c|c|}
\hline $\mathbf{A}$ & 5 \\
\hline $\mathbf{B}$ & 4 \\
\hline $\mathbf{C}$ & 3 \\
\hline $\mathbf{D}$ & 2 \\
\hline $\mathbf{E}$ & 1 \\
\hline
\end{tabular}

Tabel 4 Persentase Nilai

\begin{tabular}{|c|c|}
\hline Jawaban & Keterangan \\
\hline $0 \%-20.99 \%$ & Sangat Benar \\
\hline $30 \%-49.99 \%$ & Benar \\
\hline $50 \%-69.99 \%$ & Kurang benar \\
\hline $70 \%-89.99 \%$ & Tidak benar \\
\hline $90 \%-100 \%$ & Sangat tidak benar \\
\hline
\end{tabular}

Dari data yang didapat diatas kemudian diolah dengan cara mengkalikan setiap point jawaban dengan bobot yang sudah ditentukan dengan tabel bobot nilai

Dari hasil yang diperoleh pada tabel hasil kuesioner, maka dapat disimpulkan untuk pertanyaan pertama bahwa "Tidak Benar" Dosen selalu mempunyai waktu luang untuk kegiatan konsultasi proposal dan skripsi.
Hasil pertanyaan kedua : "Tidak Benar" kegiatan konsultasi proposal dan skripsi dapat di lakukan dimana saja dan kapan saja.

Hasil pertanyaan ke tiga : "Tidak Benar" kegiatan konsultasi proposal dan skripsi saat ini sudah efektif dan efesien.

Hasil pertanyaan ke empat : "Kurang Benar" dosen memberikan jadwal kepada mahasiswa untuk konsultasi skripsi.

Hasil pertanyaan ke lima : "Tidak Benar" mahasiswa dapat mengetahui detail nilai dari dosen penguji.

Berikut grafik dari hasilkuesioner yang telah diisi oleh responden :

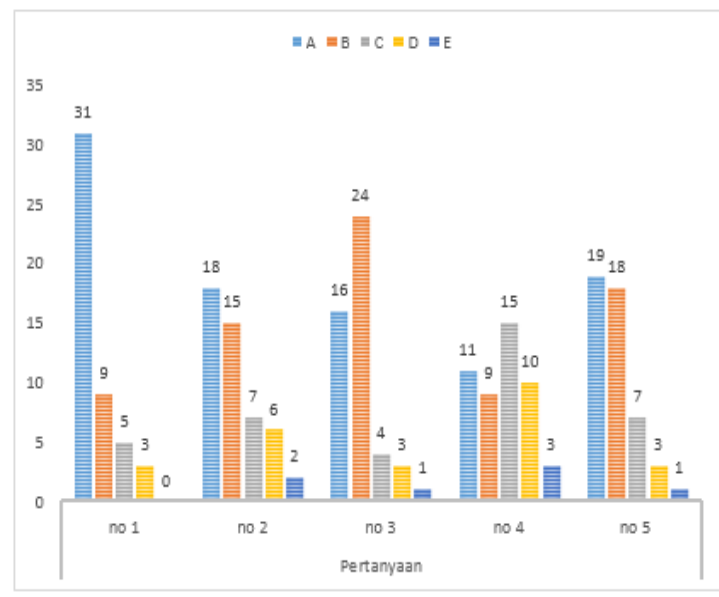

Gambar 1 grafik hasil kuisioner

\section{HASIL DAN PEMBAHASAN}

\subsection{Interface Program}

a. Menu Login

Dibawah ini merupakan interface Aplikasi :

Menu login merupakan tampilan pertama saat aplikasi dijalankan. Pada halaman login user wajib mengisi username dan password. Pada halaman ini terdapat button login yang berfungsi untuk masuk ke dalam menu utama pada sistem ini serta button cancle yang berfungsi untuk keluar dari aplikasi.

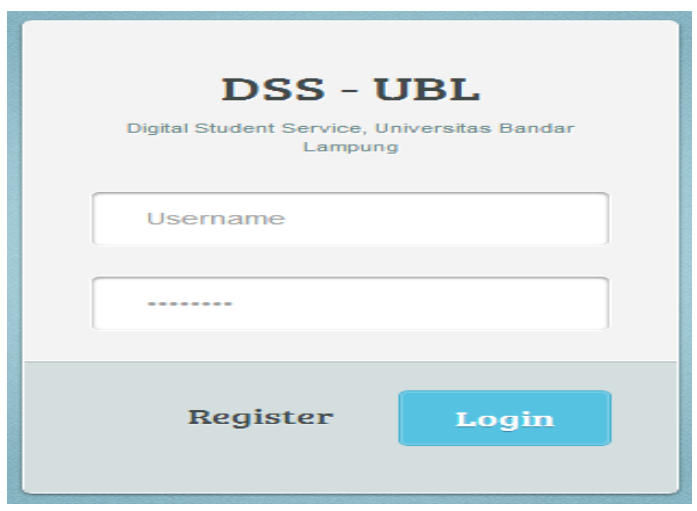

Gambar 2 Halaman Login 


\section{b. Menu Utama}

Menu utama merupakan halaman utama user setelah melakukan login, pada menu ini user dapat memilih aktifitas atau kegiatan yang di butuhkan, contohnya kegiatan konsultasi proposal.

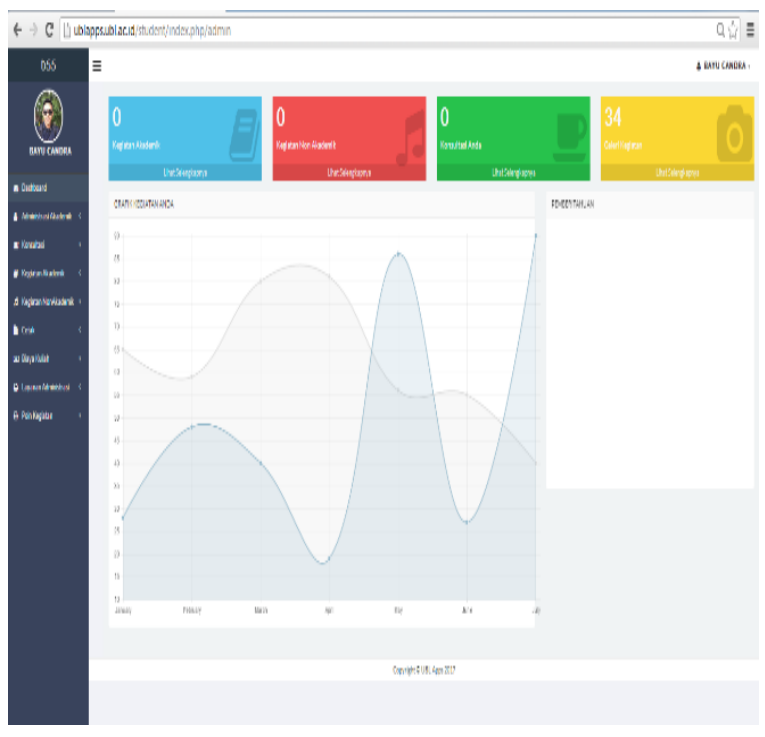

\section{Gambar 3 Menu Utama}

c. Halaman Pilih Pembimbing

Halaman ini berfungsi untuk memilih dosen pembimbing yang selanjutnya akan membimbing mahasiswa dalam konsultasi proposal hingga skripsi.

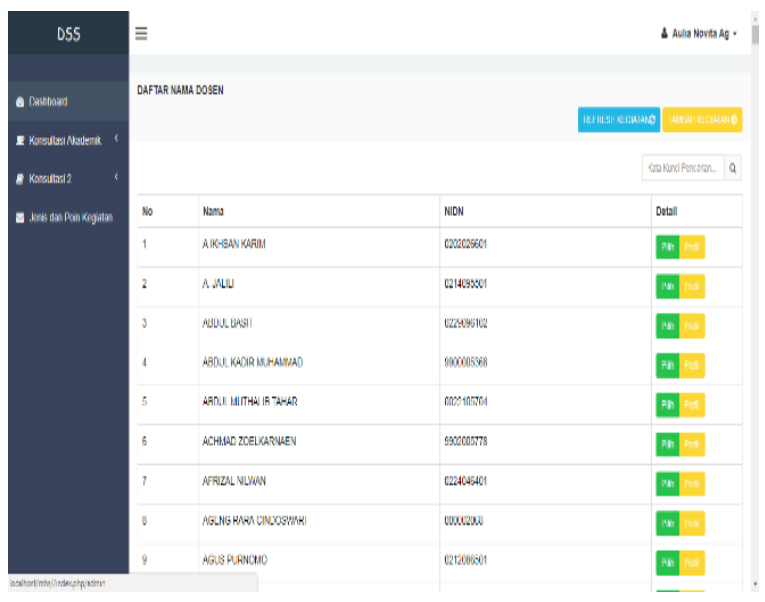

\section{Gambar 4 Halaman Menu Utama}

d. Halaman Konsultasi

Halaman ini berfungsi untuk memulai konsultasi mahasiswa dan menampilkan konsultasi'- konsultasi yang telah dilakukan (proses konsultasi).

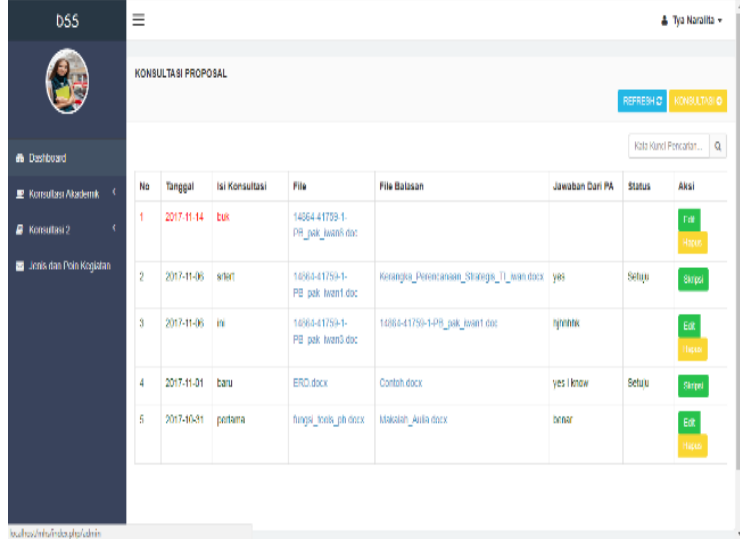

\section{Gambar 5 Halaman Konsul Proposal}

e. Halaman Form Konsultasi

Halaman form ini berfungsi untuk aktivitas mahasiswa melakukan konsultasi (mengisi form konsultasi)

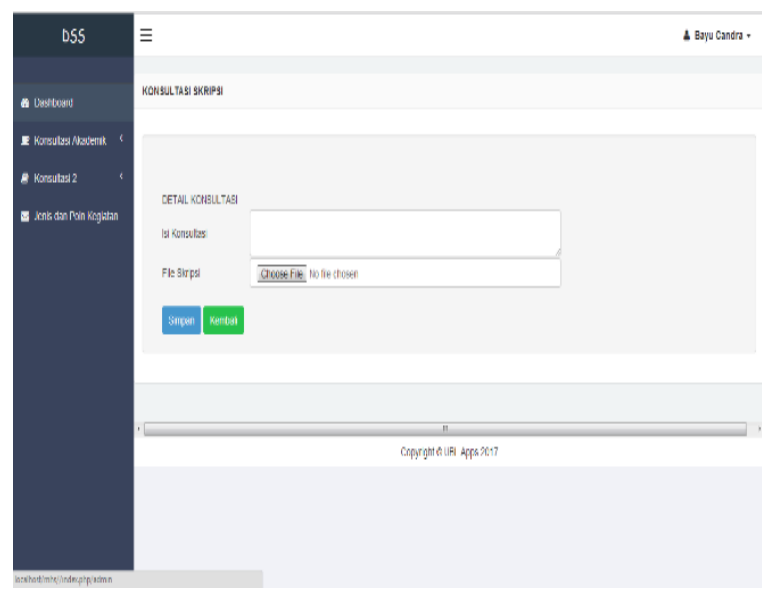

\section{Gambar 6 Konsul Proposal}

f. Halaman Upload Berkas

Pada halaman ini menu upload berkas adalah halaman rekap berkas yang sudah di upload mahasiswa.

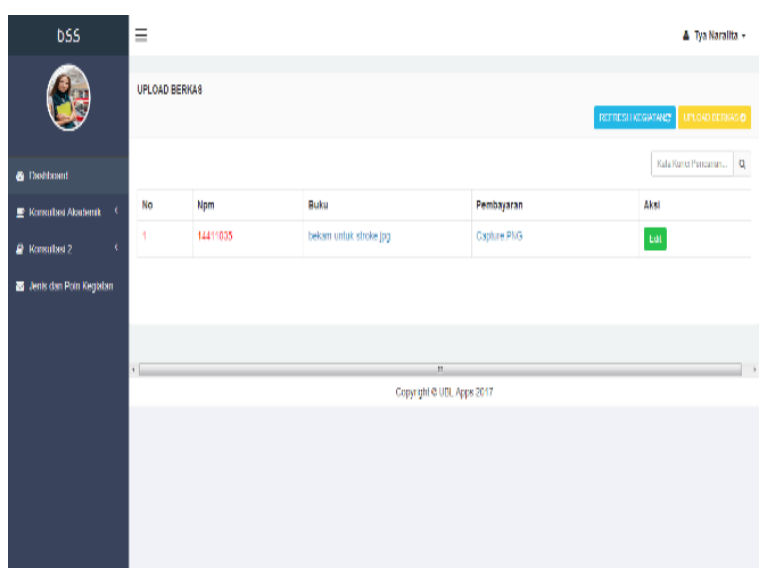

Gambar 7 Halaman Upload Berkas 
g. Halaman Daftar Mahasiswa Konsultasi

Pada halaman ini daftar mahasiswa konsultasi adalah halaman rekap daftar mahasiswa yang melakukan konsultasi, untuk melihat siapa saja mahasiswa yang sudah melakukan konsultasi ke dosen yang dipilih sebagai pembimbing.

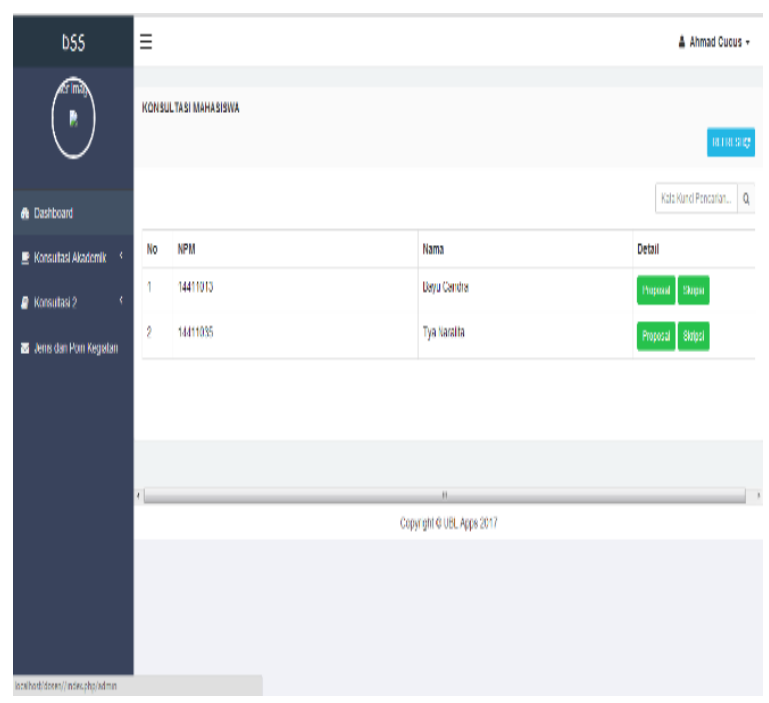

\section{Gambar 8 Halaman Daftar Mahasiswa Konsultasi}

h. Halaman Tanggapan Konsultasi (Menu dosen) Halaman tanggapan konsultasi menampilkan rekap konsultasi mahasiswa kepada dosen, di halaman ini dosen dapat melihat dan memilih konsultasi mahasiswa

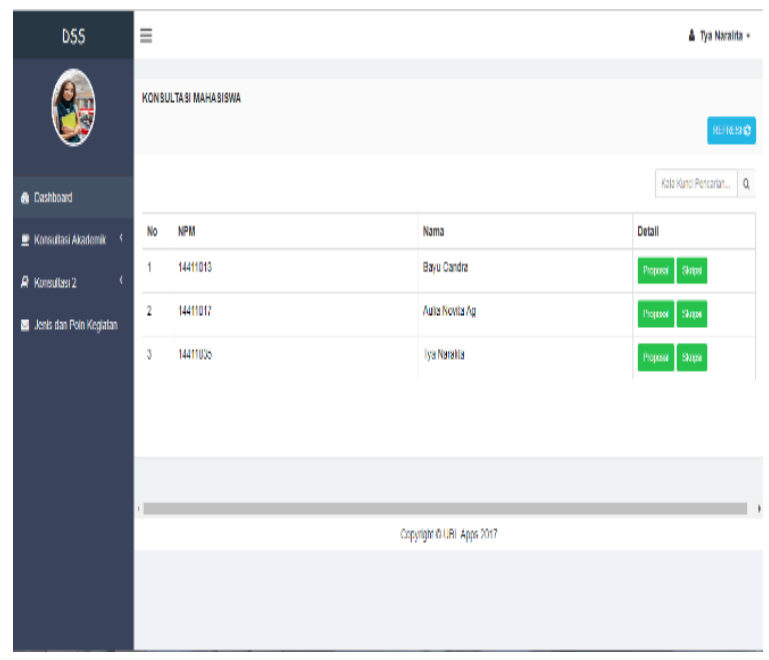

\section{Gambar 9 Halaman Tanggapan Konsul}

i. Form Tanggapan Konsultasi

Form ini berfungsi untuk menginputkan tanggapan atau balasan konsultasi dari mahasiswa yang dilakukan oleh dosen

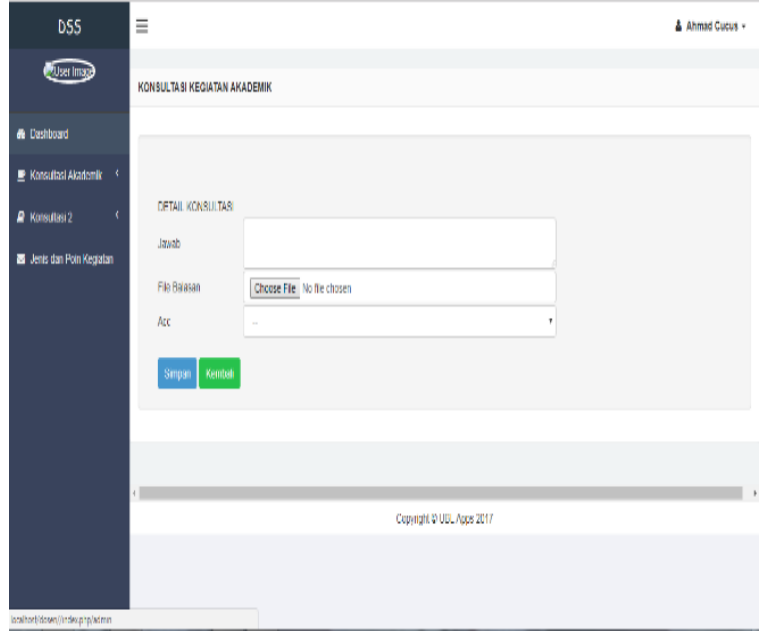

\section{Gambar 10 Form Tanggapan Konsultasi}

j. Halaman Input Nilai (Login dosen)

Halaman input nilai terdapat daftar mahasiswa yang telah selesai melakukan ujian skripsi.

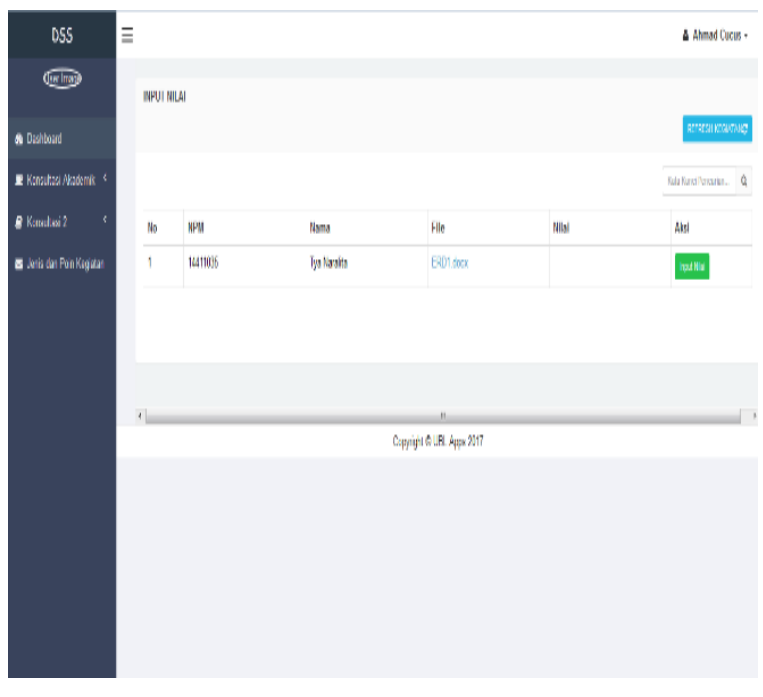

\section{Gambar 11 Halaman Input Nilai}

a. Halaman Setting Penguji

Halaman setting penguji terdapat daftar rekap mahasiswa yang sudah ditrima skripsinya oleh dosen penguji, di halaman ini juga admin fakultas dapat mengatur dosen sebagai penguji. 


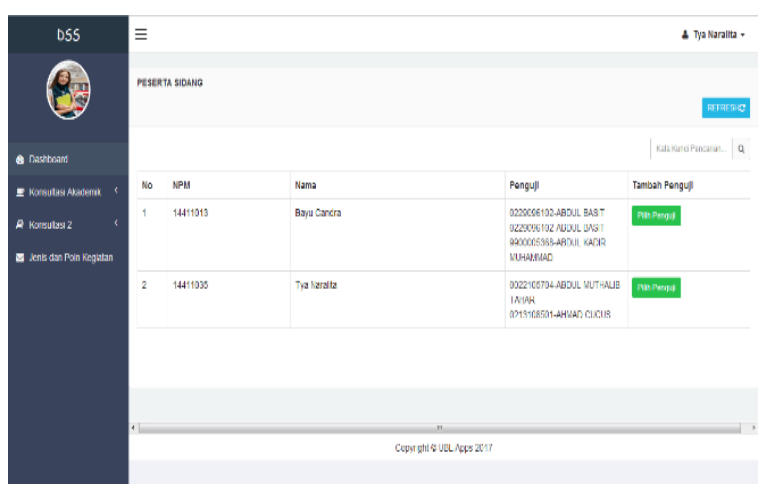

Gambar 12 Halaman Setting Penguji

b. Halaman Pilih Dosen Penguji

Halaman pilih dosen denguji admin fakultas dapat memilih daftar nama nama dosen yang akan di pilih sebagai penguji skripsi.

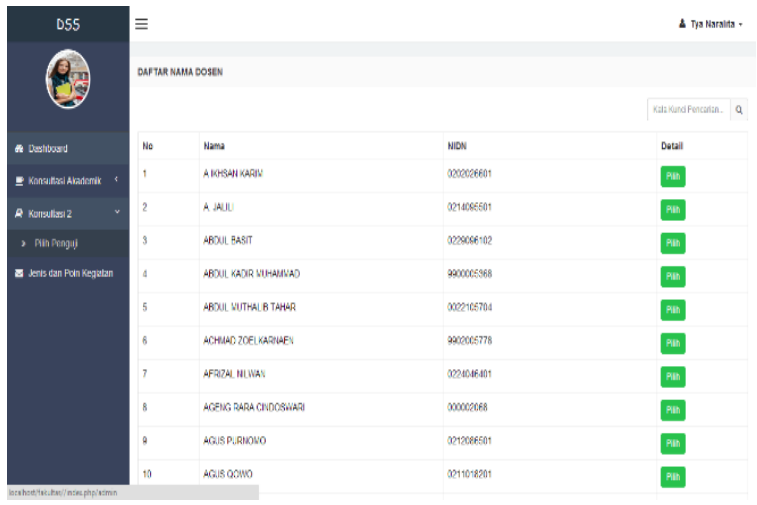

\section{Gambar 13 Pilih Dosen Penguji}

\section{c. Halaman Validasi}

Halaman validasi berfungsi untuk admin fakultas mengecek file yang mahasiswa upload, di halaman ini admin BAA dapat melihat berkas yang telah di upload mahasisswa untuk di validasi jika sudah sesuai

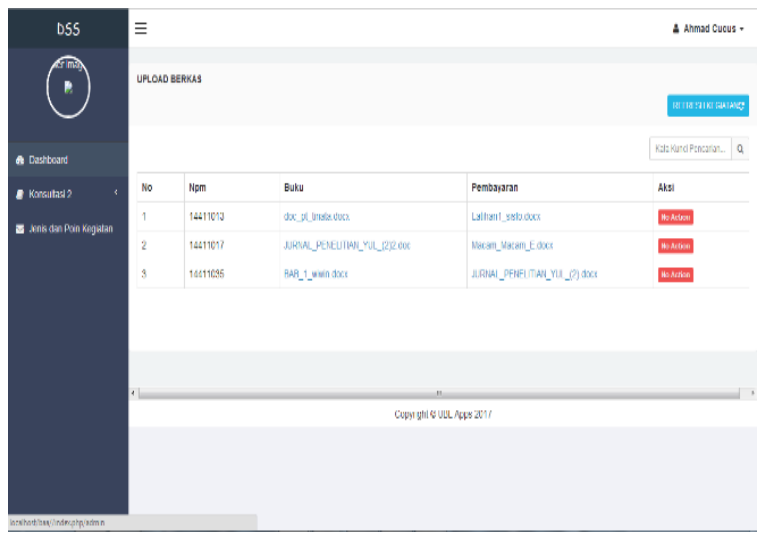

Gambar 14 Halaman Validasi d. Form Konsultasi (Login Dosen)

Halaman form Konsultasi skripsi berfungsi untuk menginput isi dan file konsultasi

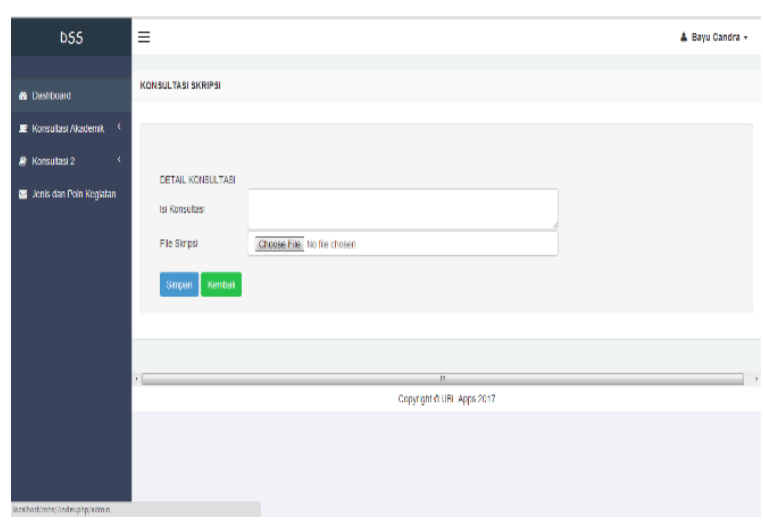

\section{Gambar 15 Konsultasi Login Dosen}

\section{k. Form Upload Berkas}

Halaman form upload berkas berfungsi untuk input berkas penyeraha buku dan bukti pembayaran.

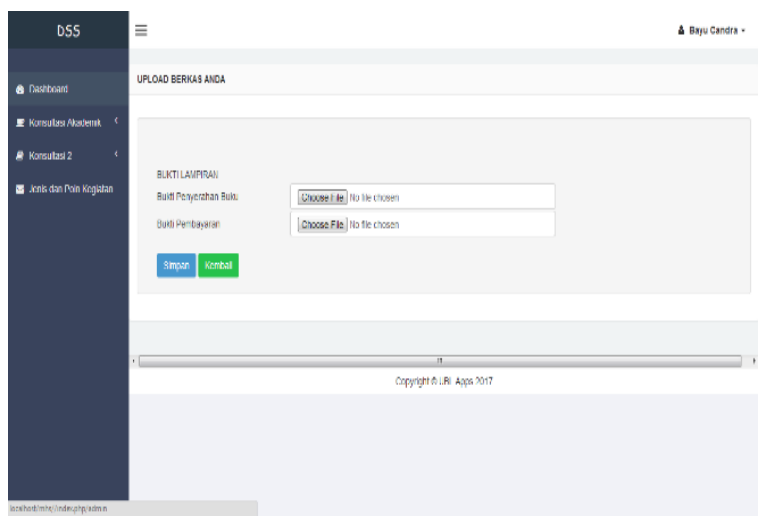

\section{Gambar 16 Form Upload Berkas}

1. Form Input Nilai

Halaman form input nilai brfungsi untuk input nilai mahasiswa yang sudah melaksanakan sidang skripsi.

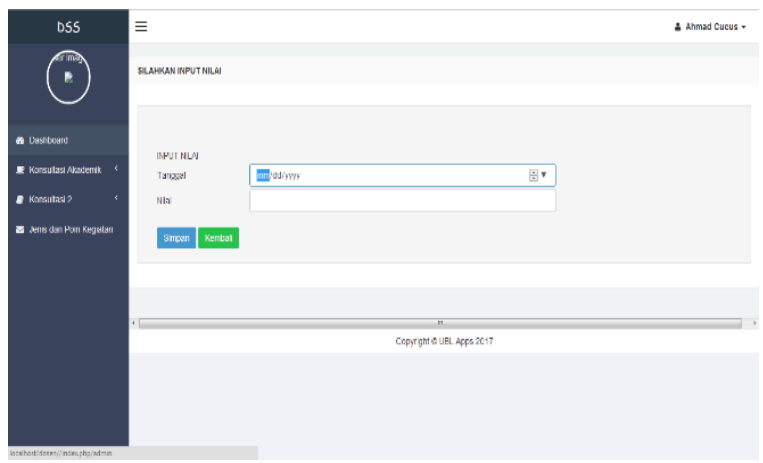

\section{Gambar 17 Form Input Nilai}


m. Form Setting Penguji

Halaman form setting penguji berfungsi untuk menentukan sttaus dosen sebagai saat menjadi penguji sidang kompre, dan menetukan nilai bobot dosen tersebut.

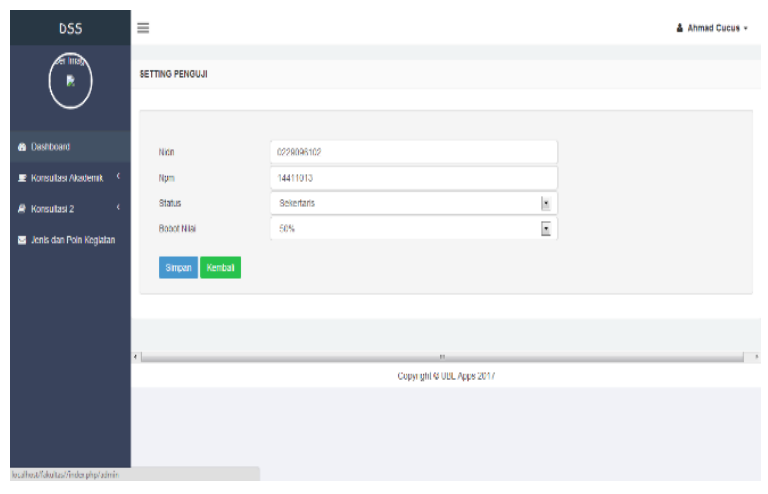

Gambar 18 Form Setting Penguji

\section{KESIMPULAN DAN SARAN}

\subsection{Kesimpulan}

Berdasarkan penelitian yang dilakukan oleh peneliti maka dapat disimpulkan bahwa :

1. Sistem Informasi yang di bangun dapat membantu meringankan tugas staff di fakultas untuk admisitrasi sidang skripsi.

2. Mengatasi masalah keterbatasan waktu padaproses konsultasi proposal serta meningkatkan kepuasan mahasiswa terhadap kinerja layanan yang diberikan.

3. Mengurangi penggunaan kertas.

4. Proses administrasi konsultasi mendukung adanya digital campus yang diterapkan di Universitas.

\subsection{Saran}

Saran yang diajukan penulis untuk penelitian selanjutnya adalah sebagai berikut :

1. Untuk kedepannya diharapkan penelitian lebih lanjut pada aplikasi ini, agar aplikasi ini menjadi lebih baik dan sesuai dengan kebutuhan penggunanya.

2. Diharapkan untuk pengembangan ataupun penelitian selanjutnya, dapat terintegrasi ke dalam proses e-banking sehingga mahasiswa yang belum melunasi seluruh administrasi pembayaran secara otomatis tidak dapat mejadi peserta sidang.

\section{DAFTAR PUSTAKA}

[1] Ariani, F, Sinaga, S, Thamrin, T.(2017). Aplikasi KEPMA untuk mengukur kepuasan mahasiswa menggunakan metode Servqual berbasis android. Expert Jurnal Menejemen Sistem Informasi dan Teknologi Volume 07 Nomor 01 Edisi Juni, 19 -24.

[2] Al-Athway, A. A. (2004). Grammatical Borrowing. The Case of Arabic.

[3] Hasnun, A. (2007). Pedoman dan Petunjuk Praktis Karya Tulis. Yogyakarta: Absolut.

[4] Heizer, J. d. (2006). Operations Management Buku2. Jakarta: Salemba empat.

[5] Jogiyanto. (2005). Analisis \& Desain Sistem Informasi. Yogyakarta: C.V Andi Offset 
Redaksi :

Pusat Studi Teknologi Informasi (PSTI). Gedung Business Center Lt 2 J. Zainal Abidin No. 26 Bandar Lampung Telp. 0721 - 774626 g 772088555000

SistemInformasi@ubl.ac.id 